ЕКСПЕРИМЕНТАЛЬНА ТА КЛІНІЧНА ФАРМАКОЛОГІЯ

K. Vovk ${ }^{1}$, O. Sokruto $^{1}$, A. Kratenko ${ }^{1}$, R. Redkin ${ }^{1}$, N. Orlovetska ${ }^{2}$, O. Dankevych ${ }^{2}$

${ }^{1}$ V. N. Karazin National University, Ukraine

${ }^{2}$ National University of Pharmacy of the Ministry of Health of Ukraine

\title{
The study of medication adherence in patients with arterial hypertension in the practice of a family doctor
}

The treatment of arterial hypertension $(\mathrm{AH})$ is one of the most significant problems of modern internal medicine. Elevated blood pressure (BP) is a major risk factor for atherosclerosis, mainly coronary heart disease and damage to the brain vessels. Medication adherence (MA) is a complex problem in patients with chronic cardiovascular diseases, especially $\mathrm{AH}$.

Aim. To study MA when treating patients with AH in a real Ukrainian out-patient practice for 8 weeks.

Materials and methods. The sample of 274 patients with AH included men and women over 18 years old with the initial level of office systolic blood pressure (SBP) of 140-179 mm Hg and diastolic blood pressure (DBP) of 99-100 mm Hg against the background of the antihypertensive therapy or without it. Initially, BP was measured at the doctor's office (office blood pressure) in all patients who were enrolled in the study; the body mass index (BMI), as well as risk factors were calculated, and the concomitant therapy was assessed. The quality of life was determined by a visual analog scale (VAS score). Patient adherence to the drug therapy was evaluated using the Morisky Medication Adherence Scale (MMAS).

Results and discussion. To conduct the study according the MMAS test all patients were distributed in two groups with low MA (MMAS $=3$ or $4, n=181$ ) or high MA (MMAS $\leq 2, n=93$ ) by the psychometric scale. The results of the MMAS test obtained were confirmed by the reliability parameter used in psychometrics (Cronbach's Alpha $>0.7)$. It was found at the end of the study that BP levels less than $140 / 90 \mathrm{~mm} \mathrm{Hg}$ of $50.6 \%$ of the Low MA group patients and $47.7 \%$ of the High MA group patients were reached. A decrease in SBP $<140 \mathrm{~mm} \mathrm{Hg}$ or a decrease in $20 \mathrm{~mm} \mathrm{Hg}$ and more from the initial level, as well as a decrease in DBP $<90 \mathrm{~mm} \mathrm{Hg}$ or $10 \mathrm{~mm} \mathrm{Hg}$ and more was observed in $98.8 \%$ of patients in the Low MA group and in $98.4 \%$ in the High MA group. After 8 weeks of observation, the quality of life significantly improved in both groups; however, in the Low MA group this improvement was more pronounced - more than 85 points instead of 82.8 by the VAS scores for the High MA group.

Conclusions. The effectiveness of the AH treatment and achievement in the target BP level depend on the patient's MA. Regular visits to the family doctor's clinic mobilize patients, and are one of the factors that increase adherence to the treatment, along with pharmaceutical care.

Key words: arterial hypertension; medication adherence; primary care; physician-patient communication; systolic blood pressure; diastolic blood pressure; Morisky Medication Adherence Scale

К. В. Вовк ${ }^{1}$, О. В. Сокруто ${ }^{1}$, А. С. Кратенкоㄱ, Р. Г. Редькін ${ }^{1}$, Н. Ф. Орловецька², О. С. Данькевич ${ }^{2}$

${ }_{1}$ Харківський національний університет імені В. Н. Каразіна, Україна

2 Національний фрармацевтичний університет Міністерства охорони здоров'я України

Дослідження прихильності до лікування у пацієнтів з артеріальною гіпертензією у практиці сімейного лікаря

Мета. Лікування артеріальної гіпертензії (АГ) - одна з найважливіших проблем сучасної медицини та фрармакотерапії. Підвищений артеріальний тиск (АТ) є основним фрактором ризику атеросклерозу, особливо хвороб серця та ураження мозкового кровообігу. Прихильність до лікування (ПЛ) є складною проблемою у пацієнтів із хронічними серцево-судинними захворюваннями, особливо АГ. Це дослідження було розроблено для визначення ПЛ під час лікування пацієнтів з АГ протягом 8 тижнів в умовах практики сімейного лікаря.

Матеріали та методи. У групі з 274 пацієнтів з АГ чоловіки та жінки 49,6-53,2 років із початковим рівнем систолічного артеріального тиску (САТ) 140-179 мм рт. ст. та діастолічного артеріального тиску (ДАТ) 99-100 мм рт. ст. на тлі антигіпертензивної терапії або без неї. Спочатку кров'яний тиск (КТ) вимірювали у всіх пацієнтів, які були записані на дослідження в кабінет лікаря (артеріальний тиск у кабінеті або офісне вимірювання КТ), розраховували індекс маси тіла, фактори ризику й оцінювали супутню фармакотерапію. Якість життя визначали за візуальною аналоговою шкалою (VAS). ПЛ в терапії оцінювали за допомогою шкали прихильності до медикаментозного лікування Моріски (MMAS). 
Результати та їх обговорення. Для проведення дослідження, згідно з тестом MMAS, усіх пацієнтів було об'єднано у дві групи: з низьким індексом ПЛ (MMAS = 3 або 4, n = 181) та високим індексом ПЛ (MMAS $\leq 2$, n = 93) психометричної шкали. Отримані результати тесту MMAS підтверджено параметром надійності, прийнятим у психометрії (коефріцієнт Альфа Кронбаха > 0,7). Наприкінці дослідження виявлено, що рівні КТ нижче 140/90 мм рт. ст. спостерігаються у 50,6 \% пацієнтів із групи з низьким ПЛ та у 47,7 \% пацієнтів із групи 3 високим ПЛ. Зниження САТ < 140 мм рт. ст. або зниження на 20 мм рт. ст. та більше від початкового рівня, а також ДАТ < 90 мм рт. ст. або зниження на 10 мм рт. ст. і більше спостерігалося у 98,8 \% пацієнтів групи з низькою ПЛ та у 98,4 \% пацієнтів групи з високою ПЛ. Після 8 тижнів спостереження якість життя значно покращилася в обох групах, але в групі з низькою ПЛ це поліпшення було більш вираженим - понад 85 балів проти 82,8 за VAS для групи з високою ПЛ.

Висновки. Ефективність лікування АГ та досягнення цільового рівня АТ залежить від прихильності пацієнта до лікування. Регулярні відвідування клініки сімейного лікаря мобілізують пацієнтів і є одним із факторів, що, поряд із фрармацевтичною опікою, збільшують прихильність до лікування.

Ключові слова: артеріальна гіпертензія; прихильність до лікування; первинна допомога; спілкування лікар-пацієнт; систолічний артеріальний тиск; діастолічний артеріальний тиск; шкала прихильності до лікування Моріски

К. В. Вовк ${ }^{1}$ О. В. Сокруто ${ }^{1}$, А. С. Кратенко ${ }^{1}$, Р. Г. Редькин ${ }^{1}$, Н. Ф. Орловецкая² , О. С. Данькевич²

${ }_{1}^{1}$ Харьковский национальный университет имени В. Н. Каразина, Украина

2 Национальный фармацевтический университет Министерства здравоохранения Украины

\section{Исследование приверженности к лечению у пациентов с артериальной гипертензией в практике семейного врача}

Цель. Лечение артериальной гипертензии (АГ) - одна из важнейших проблем современной медицины и фармакотерапии. Повышенное артериальное давление (АД) является основным фактором риска атеросклероза, особенно болезней сердца и поражения мозгового кровообращения. Приверженность к лечению (ПЛ), или комплаенс, является сложной проблемой у пациентов с хроническими сердечно-сосудистыми заболеваниями, особенно АГ. Это исследование было проведено для определения ПЛ при лечении пациентов с АГ в условиях практики семейного врача.

Материалы и методы. В группу были включены 274 пациента с АГ: мужчины и женщины 49,6-53,2 лет с начальным уровнем систолического артериального давления 140-179 мм рт. ст. и диастолического артериального давления 99-100 мм рт. ст. на фоне антигипертензивной терапии или без нее. Сначала кровяное давление (КД) измеряли у всех пациентов, которые были записаны на исследование в кабинет врача (артериальное давление в кабинете или офисное измерение КД), рассчитывали индекс массы тела, факторы риска и оценивали сопутствующую фармакотерапию. Качество жизни определяли по визуальной аналоговой шкале (VAS). ПЛ в терапии оценивали с помощью шкалы приверженности к медикаментозному лечению по тесту Мориски (MMAS).

Результаты и их обсуждение. Для проведения исследования все пациенты были разделены, согласно тесту MMAS, на две группы: с низким индексом ПЛ (MMAS = 3 или 4, $\mathrm{n}=181$ ) и высоким индексом ПЛ (MMAS $\leq 2$, $\mathrm{n}=93$ ) психометрической шкалы. Полученные результаты теста MMAS подтверждены параметром надежности, принятым в психометрии (коэфрфициент Альфа Кронбаха > 0,7). В конце исследования выявлено, что уровни КД ниже 140/90 мм рт. ст. наблюдаются у 50,6 \% пациентов группы с низким ПЛ и у 47,7 \% пациентов группы с высоким ПЛ. Снижение САД < 140 мм рт. ст. или снижение на 20 мм рт. ст. и более от исходного уровня, а также ГАО < 90 мм рт. ст. или снижение на 10 мм рт. ст. и больше наблюдалось у 98,8 \% пациентов группы с низкой ПЛ и у 98,4 \% группы с высокой ПЛ. После 8 недель наблюдения качество жизни значительно улучшилось в обеих группах, но в группе с низкой ПЛ это улучшение было более выраженным - более 85 баллов против 82,8 по VAS для группы с высокой ПЛ.

Выводы. Эффективность лечения АГ и достижения целевого уровня АД зависит от склонности пациента к лечению. Регулярные посещения клиники семейного врача мобилизуют пациентов и являются одним из факторов, увеличивающих, наряду с фрармацевтической опекой, приверженность к лечению.

Ключевые слова: артериальная гипертензия; приверженность к лечению; первичная помощь; общение врач-пациент; систолическое артериальное давление; диастолическое артериальное давление; шкала приверженности к лечению Мориски

Introduction. Diseases of the cardiovascular system are mostly chronic, i.e. they require strict long-term treatment of the patient. The treatment of arterial hypertension $(\mathrm{AH})$ is one of the most pressing problems of modern internal medicine. Elevated blood pressure (BP) is a major risk factor for atherosclerosis, mainly coronary heart disease and damage to the brain vessels [1]. Most patients in Ukraine with AH are treated in primary care, mainly in district clinics or family practice. And the fact that every year about 100 thousand inhabitants of the country suf- fers a stroke is irrefutable evidence of insufficient control of blood pressure (BP). Control of AH in Ukraine is extremely unsatisfactory as evidenced by the results of the SYSTEM-2 study. The average systolic blood pressure (SBP) in patients with $\mathrm{AH}$ visiting a family doctor or therapist (among patients taking antihypertensive drugs) is $167 \mathrm{~mm}$ $\mathrm{Hg}$, and the achievement of the target level is observed in $6.9 \%$ of cases [2]. Maintaining a multi-drug medication adherence is a complex problem in patients with chronic diseases, especially cardiovascular diseases. At the same 
time, even the use of the most effective drug or fixeddose formulations of effective agents may not succeed if the patient does not want to take the medicine regularly and clearly follow all the doctor's recommendations [3].

Initially, compliance or medication adherence (MA) in modern medicine is understood as voluntary adhering of a patient to the prescribed treatment regimen. MA is the degree to which patients follow the recommendations of their health professionals, and it specifically means the following four practical manifestations: 1) the patient takes the medicine on time; 2) he takes it in full dose; 3 ) he keeps compliance with recommendations on diet and lifestyle, and 4) for all that he does not feel the worsening of the quality of life [4]. The World Health Organization proposes that MA is affected by the following factors: 1) healthcare system or provider-patient relationship, 2) disease, 3) treatment, 4) patient characteristics, and 5) socioeconomic factors [5].

According to large-scale studies, patient adherence is a salient outcome of the process of care. In many disease conditions, non-adherence to prevention and disease management activities (e.g., medications, prescription, screening, exercise, and diet) averages $25 \%$ of patients; for some medical conditions and in some settings, adherence can be as poor as $50 \%$ or less [6]. Nevertheless, in the case of AH, the compliance of patients is only $40 \%$, while the independent withdrawal of antihypertensive drugs occurs in $\sim 60 \%$ in 6 months from the start of the treatment [7].

It is also significant to distinguish that MA is much lower in real-life settings than in clinical trials. The results of controlled trials are unlikely to be achieved in clinical practice unless specific measures are taken to improve compliance with the treatment [8]. Decrease in MA is accompanied with augmented healthcare costs, increased cardiovascular disease, and hospitalization rates. Consequently, finding non-adherent patients in outpatient settings is important in order to effectively increase $\mathrm{AH}$ control rates. Several self-reported validated questionnaires were developed to monitor MA in chronic disease patients, including hypertension patients [9]. Among them, the Morisky Medication Adherence Scale (MMAS) re- mains the best known and most widely used scale for studying medication adherence in hypertensive patients [10].

The aim of this work was to study MA when treating patients with $\mathrm{AH}$ in a real out-patient family doctor practice in Ukraine.

Materials and methods. The study was carried out in Kharkiv Polyclinic No. 26 at the premises of the Department of General Practice-Family Medicine, V. N. Karazin National University by three cardiologists and eight family doctors. The study included 274 patients with $\mathrm{AH}$; they were men and women over 18 years old with the initial level of office systolic blood pressure (SBP) of 140-179 $\mathrm{mm} \mathrm{Hg}$ and diastolic blood pressure (DBP) of 99-100 $\mathrm{mm} \mathrm{Hg}$ against the background of the antihypertensive therapy or without it. The ratio of women to men was 3 : 1 (178 women and 96 men). Exclusion criteria were symptomatic hypertension, myocardial infarction or stroke suffered less than 3 months ago, decompensated heart failure, decompensated or insulin requiring diabetes mellitus, severe impaired liver and kidney function, aortic stenosis, pregnancy and lactation (for women).

In addition to the general clinical examination, BP was measured at the doctor's office (office blood pressure) in all patients who were enrolled in the study, the body mass index (BMI) was calculated. The anamnesis, risk factors, and the concomitant therapy were assessed. The quality of life was determined by a visual analog scale (VAS score). The VAS values rating their health status on a scale from 0 (worst imaginable health status) to 100 (best imaginable health status) were determined. Each question can be scored as: having no problems (level 1), slight problems (level 2), moderate problems (level 3), severe problems (level 4), or extreme problems (level 5). The patient adherence to the drug therapy was evaluated using MMAS-4 [10]: the self-reported measure of the drug intake was developed in Ukrainian language by a four-item scale previously validated (Tab. 1). The theory underlying this measure was that failure to adhere to a medication regimen could occur due to several factors, such as "you sometimes had problems of remembering to take your medication", "you sometimes forgot to take your medication", and problems with the complexity of the medical

Table 1

The four-item MMAS

\begin{tabular}{|c|l|c|c|}
\hline $\begin{array}{c}\text { Question Item } \\
\text { number }\end{array}$ & \multicolumn{1}{|c|}{ Item } & $\begin{array}{c}\text { Standard } \\
\text { Deviation }\end{array}$ & $\begin{array}{c}\text { Proportion of "yes" } \\
\mathrm{n}=274\end{array}$ \\
\hline $\mathbf{Q 1}$ & $\begin{array}{l}\text { Do you sometimes forget to take your high blood pressure pills? } \\
\text { (No/Yes) }\end{array}$ & 0.373763 & $83.21 \%$ \\
\hline $\mathbf{Q 2}$ & $\begin{array}{l}\text { Are you careless at times about the time of taking your medicine? } \\
\text { (No/Yes) }\end{array}$ & 0.298044 & $90.15 \%$ \\
\hline $\mathbf{Q 3}$ & $\begin{array}{l}\text { When you feel better do you sometimes stop taking your medicine? } \\
\text { (No/Yes) }\end{array}$ & 0.480381 & $36.13 \%$ \\
\hline $\mathbf{Q 4}$ & $\begin{array}{l}\text { Have you ever cut back or stopped taking your medication without } \\
\text { telling your doctor because you felt worse when you took it? } \\
\text { (No/Yes) }\end{array}$ & 0.483408 & $37.23 \%$ \\
\hline
\end{tabular}

Notes: Scoring: high MA- low MA, yes = 0, no = 1. Rage: 0-4, Mean (weight) $\mathrm{n}=274$, mean for test, $x=2.47$.

Cronbach's Alpha>0.7. Split-Half (odd-even) Correlation: 0.887. Split-Half with Spearman-Brown Adjustment: 0.940.

Mean for Test: 2.467153285 . Standard Deviation for Test: 1.2085528 
Characteristics of the study participants

\begin{tabular}{|l|c|c|c|}
\hline \multicolumn{1}{|c|}{ Parameter } & $\begin{array}{c}\text { Low MA } \\
(\mathrm{n}=181)\end{array}$ & $\begin{array}{c}\text { High MA } \\
(\mathrm{n}=93)\end{array}$ & $p$ \\
\hline Women / men & $135 / 46$ & $70 / 23$ & - \\
\hline Age (years, $\mathrm{M} \pm \mathrm{m})$ & $53.2+0.2$ & $49.6+0.3$ & 0.07 \\
\hline Duration of hypertension (years, $\mathrm{M} \pm \mathrm{m})$ & $13.4+0.1$ & $12.0+0.2$ & 0.4 \\
\hline Newly diagnosed hypertension (\%) & 6.3 & 9.1 & 0.001 \\
\hline $\mathrm{SBP} \mathrm{mm} \mathrm{Hg} \mathrm{(M \pm m)}$ & $167.0 \pm 0.3$ & $165.1 \pm 0.4$ & 0.0001 \\
\hline DBP mm Hg (M m) & $99.3 \pm 0.2$ & $97.7 \pm 0.2$ & 0.0001 \\
\hline BMl, $\mathrm{kg} / \mathrm{M}^{2}(\mathrm{M} \pm \mathrm{m})$ & $27.8 \pm 0.1$ & $27.7 \pm 0.1$ & 0.7 \\
\hline Family history of the presence of hypertension (\%) & 51.9 & 51.1 & 0.7 \\
\hline Sedentary lifestyle (\%) & 55.9 & 53.8 & 0.2 \\
\hline Coronary heart disease (\%) & 43.3 & 40.4 & 0.01 \\
\hline
\end{tabular}

regimen, such as "you ever felt hassled about sticking to your treatment plan". The questions were phrased to avoid the "no/yes-saying" bias by reversing the wording of the questions about the way patients might experience failure in following their medication regimen since there was a tendency for patients to give positive answers to their physicians or other healthcare providers. Each item measured a specific medication-taking behavior and was not a determinant of adherence behavior. Response categories were yes/no for each item with a response and a 0-1-point response. The internal consistency using Cronbach's alpha $(>0.7)$ and Spearman-Brown adjustment was acceptable.

Patients were considered to be compliant, answering "no" to the questions more than 3 times (scoring more than 3 points). According to the results of the MMAS-4 test, during their first visit patients were divided into 2 groups: low medication adherence (low MA) and high medication adherence (high MA).

The therapy correction in both groups was carried out (if necessary) at the $4^{\text {th }}$ week of the study. In their final visit (in 8 weeks) patients were again invited to the clinic. The therapy was considered to be effective when at the end of the observation the target office blood pressure was less than 140/90 $\mathrm{mm} \mathrm{Hg}$. The effectiveness of the therapy was evaluated as the percentage of patients who reached the target level of BP, the percentage of patients with a decrease in DBP more than $10 \mathrm{~mm} \mathrm{Hg}$, and the percentage of patients with a decrease in SBP more than $20 \mathrm{~mm} \mathrm{Hg}$ from the initial level. The quality of life was assessed by VAS (baseline-endpoint).

The statistical analysis was performed using the "SAS software" package (version 6.12). In the analysis, mean values $(\mathrm{M})$ and their standard errors $(\mathrm{m})$ were calculated. The significance of differences in average values was assessed by the Student's criterion ( $\mathrm{t}$ ). The programs of parametric and nonparametric analysis were used. The results were considered to be reliable at $\mathrm{p}<0.05$. Data were presented as $\mathrm{M} \pm \mathrm{m}$. To estimate the reliability of the psychometric test Cronbach's Alpha, Split-Half(odd-even) correlation, Split-Half with Spearman-Brown Adjustment, etc., were found.
Results and discussion. All patients examined completed this study. The groups did not differ in age, duration of hypertension, burdened heredity, BMI and degree of physical activity. In the group with Low MA, the level of SBP and DBP was significantly higher than in the group with High MA. It was noted that in the Low MA group associated diseases were less common, and they were less likely to receive the drug therapy (Tab. 2).

Against the background of the treatment in 4 and 8 weeks a significant decrease in the level of both SBP and DBP was observed in both groups (Fig. 1). At the same time, at the end of the study, the level of SBP decreased by an average of $31 \mathrm{~mm} \mathrm{Hg}$, and DBP by $15 \mathrm{~mm} \mathrm{Hg}$ $(\mathrm{p}<0.0001)$.

By the end of the study, the blood pressure level less than $140 / 90 \mathrm{~mm} \mathrm{Hg}$ was reached by $50.6 \%$ of patients of the Low MA group and $47.7 \%$ of patients of the High MA group. A decrease in $\mathrm{SBP}<140 \mathrm{~mm} \mathrm{Hg}$ or a decrease in $20 \mathrm{~mm} \mathrm{Hg}$ and more from the initial level, as well as a decrease in DBP $<90 \mathrm{~mm} \mathrm{Hg}$ or $10 \mathrm{~mm} \mathrm{Hg}$ and more was observed in $98.8 \%$ of patients in the Low MA group and in $98.4 \%$ in the High MA group.

The study of the quality of life is an important aspect for evaluating the ongoing therapy. The analysis of VAS score data at the beginning of the study revealed a significantly lower quality of life in the group of patients with Low MA. After 8 weeks of observation, the quality

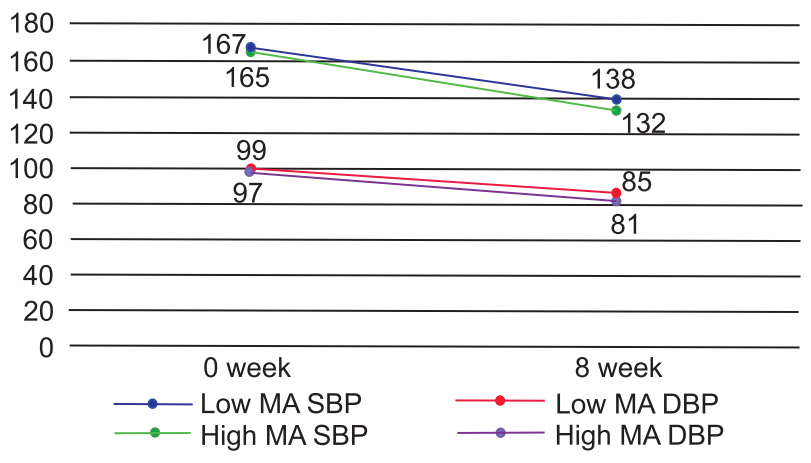

Fig. 1. The dynamics of BP lowering during the study, $\mathrm{mm} \mathrm{Hg}$ $(p<0.0001)$ 
of life significantly improved in both groups; however, in the Low MA group this improvement was more pronounced - more than 85 points instead of 82.8 for the High MA group (Fig. 2).

When asked about the therapy tolerability patients answered as excellent and good in $79 \%$ of cases (Low MA group) and in $80.4 \%$ of cases (High MA group) $(p=0.7)$. Improvement in well-being was noted in $95 \%$ of patients in the Low MA group and $94.2 \%$ of patients in the High MA group $(p=0.3)$. Well-being did not change (according to the subjective assessment of patients) in $5 \%$ of cases in the Low MA group and in $5.8 \%$ of cases in the High MA group.

The dynamics of adherence to therapy during the treatment was analyzed by assessing markers of the lack of adherence to the drug therapy: the presence of psychological problems, especially depression; the presence of cognitive impairment, as a result of which the patient simply could not understand why he should be treated or could forget to take the drug; asymptomatic disease; the lack of contact with a doctor, inadequate observation and recommendations written in poorly readable handwriting; side effects; poor awareness of the disease; complexity of therapy; high cost of the treatment.

It should be mentioned that all difficulties were mainly associated with three main reasons: the reasons associated with the patient (rejection of treatment, fear of a large number of drugs, and, as a result, incorrect intake of drugs); high cost of therapy, especially the multicomponent one; a complex regimen of administration and, accordingly, a high probability of deviation from the scheme (for example, when prescribing 4 drugs, the probability of compliance was reduced by half).

During the treatment there was a significant increase in adherence to the treatment in both groups of patients. Moreover, in the group with the initial Low MA a more pronounced change in the answers to the questions of the MMAS test was observed.

In the analysis of the Low MA group, it was noted that 58 patients were not compliant to the therapy. At the same time, 123 patients in the group with Low MA during their final visit showed an increase in adherence to the therapy (according to the MMAS test). In the High MA group, 13 patients became less compliant, while 80 patients remained highly compliant (Fig. 3).

The treatment adherence and treatment retention are significantly reduced over time. Therefore, according to

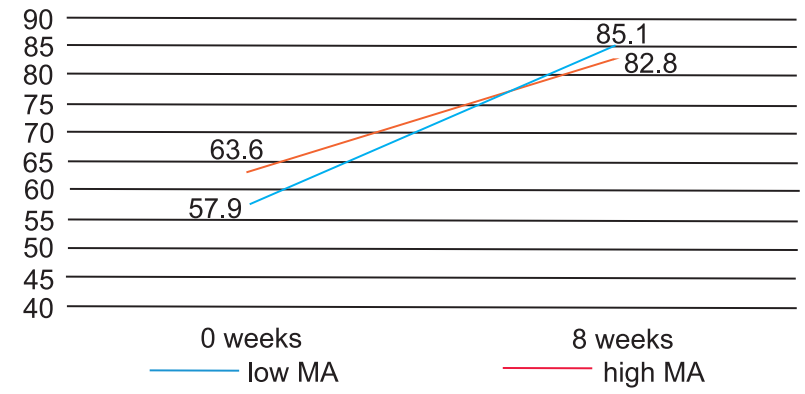

Fig. 2. The mean VAS score $(\mathrm{M} \pm \mathrm{m})$ with the $95 \%$ confidence interval before and after 8 weeks of the therapy the literature, only $61.8 \%$ of patients with hypertension and $65.6 \%$ regularly take prescribed drugs after a year of their treatment. When analyzing the regularity of treatment it was found that only $23.5 \%$ of patients took prescribed drugs all the time, while $76.5 \%$ of patients administered drugs only with an increase in blood pressure, were treated with courses, or did not take prescribed drugs at all. Thus, in most cases, patients with hypertension are not committed to therapy.

In this study, $31 \%$ patients were not committed to the therapy. We analyzed factors that could affect adherence to the therapy in these patients: gender, age, the presence of a coronary heart disease, duration of hypertension, the smoking status, lifestyle, taking medications, the ability to measure blood pressure at home. Such a parameter as the inclusion of drugs in the "Available Medicines" Ukrainian national program was of particular interest.

Women were more adherent to the therapy $(\mathrm{p}<0.0001)$. Adherence to the treatment decreased with age $(\mathrm{p}<0.004)$. Patients with a coronary artery disease were highly committed to the therapy $(\mathrm{p}<0.0001)$. The presence of home blood pressure monitors and the ability to control blood pressure also determined an increased adherence to the drug therapy $(\mathrm{p}<0.03)$. Patients who smoke were less committed to the therapy than non-smokers $(\mathrm{p}<0.0002)$. Patients with a sedentary lifestyle were also less committed to therapy than people with an active lifestyle $(p<0.003)$. The analysis of the drugs used by patients showed that the most adherent to the therapy were patients taking high-cost drugs, for example, alpha-2 receptors blockers. We conducted a multivariate analysis of the contribution of the above parameters to adherence to the therapy. When evaluating the basic model adjusted for gender and age the contribution of drugs included in the "Available Medicines" program to adherence to the therapy was very high $(<0.00001)$. The presence of the drug in the "Available Medicines" list and its delivery to the patient significantly increased adherence to the therapy $(p<0.0001)$. However, with the gradual inclusion of parameters, such as the presence of concomitant coronary heart disease, in the analysis there was a gradual decrease in the contribution of drugs in the "Available Medicines" program to adherence to the therapy.

Thus, the availability of the drug in the list of the "Available Medicines" program is not an independent and determining factor in adherence to the treatment. Patients,

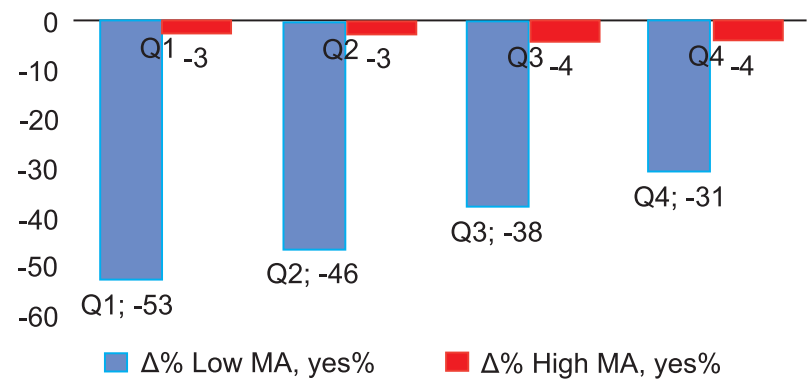

Fig. 3. The dynamics of the number of patients with a positive answer to the questions (Q1-Q4) of the MMAS test during the study $(p<0.0001)$ 
who understand the need for regular use of prescribed drugs, consciously set themselves up for the treatment; they will buy drugs regardless of the presence or absence of them in the list of the "Available Medicines" program.

It is noteworthy that in the group with low MA the level of blood pressure decreased similarly as in the group of patients with high MA. The level of blood pressure did not practically differ between the groups during the last visit. Several points can explain this fact. During the treatment there was a significant improvement in compliance in both groups. Moreover, in the group with the initially low compliance this improvement was more pronounced. It was noted that a large proportion of patients (41\%) who were not compliant with the treatment during the initial visit became committed to the treatment by the end of the observation $(p=0.001)$. Patients visited the clinic doctor in 1 and 2 months, and it mobilized patients, being one of the factors in increasing adherence to the treatment.

A very important point in the outpatient monitoring and treatment is the assessment of the quality of life. With poor tolerance of the treatment, a difficult regimen of taking medications, as well as deterioration in the pati- ent's well-being the quality of life decreases. Improving the quality of life motivates patients to take drugs prescribed by visiting a physician, and it, in turn, is one of the factors for increasing compliance on an outpatient basis. In our study, there was a significant improvement in the quality of life, more pronounced in the group with the initially low MA. In addition, the majority of patients in the Low MA group showed a significant increase in adherence to the treatment at the endpoint.

Conclusions and prospects of further research. Our pilot study of MA of AH patients in the practice of a family doctor indicates that effectiveness of treating hypertension (achieving the target level of BP) depends on MA with the treatment. Furthermore, MA and the patient's retention on therapy decrease significantly over time. Nevertheless, regular visits to the family doctor's clinic mobilize patients. It is one of the factors to increase adherence to the treatment and improve the patient's quality of life, even in a group with low adherence to treatment. The presence of the drug in the "Available Medicines" Ukrainian national program is not an independent factor determining the patient's adherence to the therapy.

Conflict of interests: authors have no conflict of interests to declare.

\section{REFERENCES}

1. Global burden of hypertension and systolic blood pressure of at least 110 to $115 \mathrm{~mm} \mathrm{Hg}, 1990-2015$ / M. H. Forouzanfar et al. Journal of the American Medical Association. 2017. Vol. 317, Iss. 2. P. 165-182. DOI: https://doi.org/10.1001/jama.2016.19043.

2. Реалии лечения артериальной гипертензии в Украине: результаты когортного исследования СИСТЕМА-2 / В. И. Целуйко и др. Український кардіологічний журнал. 2018. Т. 25, № 1. C. 13-20. URL: http://www.ucardioj.com.ua/index.php/UJC/article/view/45.

3. Relationship between patients' knowledge and medication adherence among patients with hypertension / B. Jankowska-Polańska et al. Patient Preference and Adherence. 2016. Vol. 10. P. 2437-2447. DOI: https://doi.org/10.2147/PPA.S117269.

4. DiMatteo M. R. Variations in Patients'Adherence to Medical Recommendations: A Quantitative Review of 50 Years of Research. Medical Care. 2004. Vol. 42, Iss. 3. P. 200-209. DOI: https://doi.org/10.1097/01.mlr.0000114908.90348.f9.

5. Adherence to long-term therapies : evidence for action / eed. by E. Sabatép. World Health Organization. 2003p. URL: https://apps.who.int/ iris/handle/10665/42682.

6. Prevention of cardiovascular disease : guidelines for assessment and management of total cardiovascular riskl. World Health Organization. 2007. URL: https://apps.who.int/iris/handle/10665/43685.

7. Prevalence and correlates of self-reported medication non-adherence among older adults with coronary heart disease, diabetes mellitus, and/or hypertension / Z. A. Marcum et al. Research in Social and Administrative Pharmacy. 2013. Vol. 9, Iss. 6. P. 817-27. DOI: https:// doi.org/10.1016/j.sapharm.2012.12.002.

8. Nonadherence to antihypertensive drugs: A systematic review and meta-analysis / T. M. Abegaz et al. Medicine (Baltimore). 2017. Vol. 96, Iss. 4. P. e5641. DOI: https://doi.org/10.1097/MD.0000000000005641.

9. Compliance among adolescents with arterial hypertension / A. Paczkowska et al. Advances in Clinical and Experimental Medicine. 2016. Vol. 25, Iss. 3. P. 441-448. DOI: https://doi.org/10.17219/acem/33838.

10. Predictive validity of a medication adherence measure in an outpatient setting / D. E. Morisky et al. The Journal of Clinical Hypertension. 2008. Vol. 10, Iss 5. P. 348-354. DOI: https://doi.org/10.1111/j.1751-7176.2008.07572.x.

\section{REFERENCES}

1. Forouzanfar, M. H., Liu, P., Roth, G. A., Ng, M., Biryukov, S., Marczak, L, Ali, R. (2017). Global burden of hypertension and systolic blood pressure of at least 110 to $115 \mathrm{~mm} \mathrm{Hg}, 1990-2015$. Journal of the American Medical Association, 317 (2), 165-182. doi: https:// doi.org/10.1001/jama.2016.19043.

2. Tseluiko, V. I., Avilova Ya. M., Alchinskii, I. V., Antipenko, I. D. (2018). Realii lecheniya arterialnoy gipertenzii v Ukraine: rezultatyi kogortnogo issledovaniya SISTEMA-2. Ukrainskyi kardiolohichnyi zhurnal, 1, 13-20. Available at: http://www.ucardioj.com.ua/index. $\mathrm{php} / \mathrm{UJC} / \mathrm{article} / \mathrm{view} / 45$.

3. Jankowska-Polańska, B., Uchmanowicz, I., Dudek, K., Mazur, G. (2016). Relationship between patients' knowledge and medication adherence among patients with hypertension. Patient preference and adherence, 10, 2437-47. doi: 10.2147/PPA.S117269.

4. DiMatteo, M. (2004). Variations in Patients' Adherence to Medical Recommendations: A Quantitative Review of 50 Years of Research. Medical Care, 42 (3), 200-209. doi:10.1097/01.mlr.0000114908.90348.f9.

5. Sabaté, E. (2003). Adherence to long-term therapies: evidence for action. Geneva, World Health Organization. Available at: https://apps. who.int/iris/handle/10665/42682 
6. World Health Organization. (2007). Prevention of cardiovascular disease: Guidelines for assessment and management of cardiovascular risk. Geneva, WHO. Available at: https://apps.who.int/iris/handle/10665/43685.

7. Marcum, Z. A., Zheng, Y., Perera, S., Strotmeyer, E., Newman, A. B., Simonsick, E. M. et al. (2013). Prevalence and correlates of selfreported medication non-adherence among older adults with coronary heart disease, diabetes mellitus, and/or hypertension. Research in Social and Administrative Pharmacy, 9 (6), 817-827. doi: https://doi.org/10.1016/j.sapharm.2012.12.002.

8. Abegaz, T. M., Shehab, A., Gebreyohannes, E. A., Bhagavathula, A. S., Elnour, A. A. (2017). Nonadherence to antihypertensive drugs: a systematic review and meta-analysis. Medicine, 96 (4), e5641. doi:10.1097/MD.0000000000005641

9. Paczkowska, A., Kopciuch, D., Nowakowska, E., Hoffmann, K., Bryl, W. (2016). Compliance among adolescents with arterial hypertension. Advances in Clinical and Experimental Medicine, 25 (3), 441-448. doi: https://doi.org/10.17219/acem/33838.

10. Morisky, D. E., Ang, A., Krousel-Wood, M., Ward, H. J. (2008). Predictive validity of a medication adherence measure in an outpatient setting. The Journal of Clinical Hypertension, 10 (5), 348-354. doi: https://doi.org/10.1111/j.1751-7176.2008.07572.x.

\section{Information about authors:}

Vovk K., Candidate of Medicine (Ph.D), associate professor of the Department of General Practice - Family Medicine,

V. N. Karazin Kharkiv National University. E-mail: k.vovk@karazin.ua. ORCID: https://orcid.org/0000-0003-2971-0842

Sokruto O., Candidate of Medicine (Ph.D), associate professor of the Department of General Practice - Family Medicine,

V. N. Karazin Kharkiv National University. E-mail: o.sokruto@karazin.ua. ORCID: https://orcid.org/0000-0001-9501-6686

Kratenko A., Candidate of Medicine (Ph.D), associate professor of the Department of General Practice - Family Medicine,

V. N. Karazin Kharkiv National University. E-mail: annakratenko@karazin.ua. ORCID: https://orcid.org/0000-0001-7019-5593

Redkin R., Candidate of Pharmacy (Ph.D), associate professor of the Department of General Practice - Family Medicine,

V. N. Karazin Kharkiv National University. E-mail: ruslan.red.chem@gmail.com. ORCID: https://orcid.org/0000-0003-4412-0496

Orlovetska N., Candidate of Pharmacy (Ph.D), associate professor of the Drug Technology Department, National University of Pharmacy

of the Ministry of Health of Ukraine. E-mail: ninelorlv@gmail.com

Dankevych O., Candidate of Pharmacy (Ph.D), associate professor of the Drug Technology Department, National University of Pharmacy

of the Ministry of Health of Ukraine. E-mail: os.dank@gmail.com. ORCID: https://orcid.org/0000-0002-3030-2769

Відомості про авторів:

Вовк К. В., кандидатка мед. наук, доцентка кафедри загальної практики - сімейної медицини, Харківський національний університет імені В. Н. Каразіна. E-mail: k.vovk@karazin.ua. ORCID: https://orcid.org/0000-0003-2971-0842

Сокруто О. В., кандидатка мед. наук, доцентка кафедри загальної практики - сімейної медицини, Харківський національний університет імені В. Н. Каразіна. E-mail: o.sokruto@karazin.ua. ORCID: https://orcid.org/0000-0001-9501-6686

Кратенко А. С., кандидатка мед. наук, доцентка кафедри загальної практики - сімейної медицини, Харківський національний університет імені В. Н. Каразіна. E-mail: annakratenko@karazin.ua. ORCID: https://orcid.org/0000-0001-7019-5593

Редькін Р. Г., кандидат фарм. наук, доцент кафедри загальної практики - сімейної медицини, Харківський національний університет імені В. Н. Каразіна. E-mail: ruslan.red.chem@gmail.com. ORCID: https://orcid.org/0000-0003-4412-0496

Орловецька Н. Ф., кандидатка фарм. наук, доцентка кафедри технології ліків, Національний фармацевтичний університет Міністерства охорони здоров'я України. E-mail: ninelorlv@gmail.com

Данькевич О. С., кандидатка фарм. наук, доцентка кафедри технології ліків, Національний фармацевтичний університет

Міністерства охорони здоров'я України. E-mail: os-dank@gmail.com. ORCID: https://orcid.org/0000-0002-3030-2769

Сведения об авторах:

Вовк К. В., кандидат мед. наук, доцент кафедры общей практики - семейной медицины, Харьковский национальный университет имени В. Н. Каразина. E-mail: k.vovk@karazin.ua. ORCID: https://orcid.org/0000-0003-2971-0842

Сокруто О. В., кандидат мед. наук, доцент кафедры общей практики - семейной медицины, Харьковский национальный университет имени В. Н. Каразина. E-mail: o.sokruto@karazin.ua. ORCID: https://orcid.org/0000-0001-9501-6686

Кратенко А. С., кандидат мед. наук, доцент кафедры общей практики - семейной медицины, Харьковский национальный университет имени В. Н. Каразина. E-mail: annakratenko@karazin.ua. ORCID: https://orcid.org/0000-0001-7019-5593

Редькин Р. Г., кандидат фарм. наук, доцент кафедры общей практики - семейной медицины, Харьковский национальный университет имени В. Н. Каразина. E-mail: ruslan.red.chem@gmail.com. ORCID: http://orcid.org/0000-0003-4412-0496

Орловецкая Н. Ф., кандидат фарм. наук, доцент кафедры технологии лекарств, Национальный фармацевтический университет Министерства здравоохранения Украины. E-mail: ninelorlv@gmail.com

Данькевич О. С., кандидат фарм. наук, доцент кафедры технологии лекарств, Национальный фармацевтический университет Министерства здравоохранения Украины. E-mail: os.dank@gmail.com. ORCID: https://orcid.org/0000-0002-3030-2769 